\title{
The Dartmouth Dante Project
}

Robert Hollander

\section{History of the Project}

In June of 1982 I was teaching a course on Dante at Dartmouth College. Taking note of the fact that three of my colleagues there (Kevin Brownlee, Stephen Nichols, Nancy Vickers) were increasingly interested in dealing seriously with Dante in their scholarship and of the fact that Dartmouth's holdings in this area are not strong, I was struck by the idea that a computerized database of the commentaries would not only alleviate the situation of my colleagues at Dartmouth, but of dantisti everywhere. I have elsewhere characterized this notion as "the best simple idea 1 have ever had"-a statement which perhaps suggests inaccurately that I have had good complex ideas. Dartmouth, as many know, under the guidance of its president, John Kemeny, had become one of the campuses in the world most involved in making the computer serve all parts of its curriculum. It was-and is-a fertile soil for this project. By the end of August 1982 responses from my three colleagues in French \& Italian, from the computer people (principally Raymond Neff, then Director of Academic Computing at the Kiewit Computational Center at Dartmouth), and from the Dartmouth administration were all encouraging enough to get the project started. In May of 1983 the Dante Society of America offered $\$ 2000$ in start-up funds; Dartmouth itself soon made available some $\$ 20,000$. Neff and the four humanists consulted through the following summer and produced an application to the National Endowment for the Humanities. This was successful. On 1 October 1984 the project began a more intense phase of its existence, supported by $\$ 120,000$ for that fiscal year (1984-85) and by the same amount for 1985-86 (in the form of $\$ 60,000$ raised by Dartmouth to match an offer of that same amount in "Gifts and Match" from NEH). In August of 1986 we learned that our second application to NEH had also been successful, this time in 
the amount of $\$ 150,000$ of outright funds, with the potential to raise a second federal match of $\$ 60,000$ in non-federal funds. As of the end of 1987, gifts from the David and Lucile Packard Foundation, Apple Computer, Princeton University, and the AT \& T Educational Foundation had brought us to that total. We still need to find ca. $\$ 180,000$ in order to complete our editing of the machine-readable texts.

During the academic year 1982-83 Raymond Neff and a team of six graduate students in computer science at Dartmouth put together a working prototype of the project, based on some two dozen commentaries to Inferno 5.121-138. In the summer of 1983 it was-when the user-interface was not too fragile- a joy to watch visiting firemen sit before a terminal in Kiewit Center and call up commentaries to a designated verse or search the tiny database by "key words," or wonder if one of these commentators had thought of St. Augustine's conversion in relation to Francesca's being "converted" by her reading of the Lancelot romance to lustful passion (none had). The prototype had many problems, but did show us that these were worth resolving and were, indeed, resolvable.

Life generally contrives to make all plans seem contingent. Just as the project was moving into full-scale operation in the fall of 1984, Raymond Neff was lured from Dartmouth to Berkeley. William Arms, acting director of Kiewit Center, agreed to serve as acting codirector of the project, until he too was soon set upon by foreigners, this time in the form of Carnegie-Mellon. Since 1985 our co-director has been Donald Spicer, Director of Academic Computing at Dartmouth, who took the place previously occupied in the project by Neff and Arms. By 1988 Notre Dame had picked off Spicer; David Bantz, Dartmouth's chief of humanistic computing, is now co-director. During the academic year 1984-85 Jeffrey Schnapp, then an assistant professor of French \& Italian at Dartmouth, both a dantista and a highly "computer-literate" young scholar, became the administrator of the database. His efforts on behalf of the project were crucial; he single-handedly galvanized and co-ordinated the two dozen or so graduate and undergraduate students at Dartmouth who put data into the computer. He, too (need I tell it?) was soon to be wooed to California (Stanford). Janet Stephens, who had been trained by Schnapp, assumed this key position in September of 1985. She and a gradu- 
ate student, Ty Cannon, were in charge of the day-to-day operation of the procedures of data entry during the academic year 1985-86. During the next year Jonathan Altman, a junior at Dartmouth, took on increasing responsibility, taking over Janet Stephens's tasks while she was in ltaly during the fall of 1986 . We have been extremely well served by this group of people and by various administrators, faculty, personnel at Kiewit Center, and students at Dartmouth College. The central players now seem to be in place for the life of the project. The two other key members of our staff are Margherita Frankel, formerly associate professor of Italian at New York University and a dantista, who is serving as editorial co-ordinator for the project (she has been part of our deliberations since July of 1983) and Stephen Campbell, a computer programmer, who has become the central figure on the computational side of the enterprise, in charge of the adaptation and development of the software which will power the manipulation of the database. The project now uses a VAX (Digital Equipment Company) 785 computer running the Unix (AT\&T) timesharing system and a text retrieval database developed by BRS Information Systems.

The entering of the database, which, we estimate, will be the equivalent of some 150,000 typed pages, was, from the beginning, our principal concern. During the summer of 1983 Kiewit Center purchased a Kurzweil Data Entry Machine (henceforth the KDEM). This remarkable instrument allows itself to be programmed to "read" a given typeface or set of typefaces in a document. At first we had any number of problems with the KDEM. Its error-rate was sharply reduced once we offered it enlarged photocopy of smaller typefaces. This and other techniques which have been developed by Schnapp, Cannon, Stephens, and Campbell are now procuring results that more than justify the expense (ca. $\$ 0.75$ per page) of the KDEM operation. The KDEM's rate of accuracy, while it varies with the quality of text which we present it, is now ca. $99.9 \%$. Editing is of course still necessary, but not overly difficult, especially because of the preediting techniques developed by Altman, Stephens, and Campbell. (The Digital Equipment Company has contributed equipment-seven work stations worth $\$ 41,000$ - to the editorial phase of the project.) The text of all commentaries must be checked; some two dozen require the addition of verse numbers to the entries so that retrieval 
throughout the database may be uniform. Nearly all of the commentaries are readable by the KDEM. However, we have found that some either have typefaces too difficult for consistent recognition of their characters or are in such poor condition (e.g., spotted pages, uneven inking) so that manual entry is necessary or at least more desirable. The positive side of this development is that we are proceeding with two modes of data entry, a fact which enables us to put in data more rapidly. The most difficult text we could find for the KDEM to "read" was that of Bernardino Daniello (first printed in 1568 and not reprinted in its entirety since then). This interesting Renaissance commentary has now been entered, by hand. The first printed byproduct of the Dartmouth Dante Project, this text will be published within the year by University Press of New England. Schnapp and Hollander, with assistance from Vickers and Brownlee, added documentation to Daniello's citations of the Bible and of secular authors and have also produced an index of citations (computer-generated, I need hardly add).

As of August 1988 all but five commentaries are machine-readable. We expect that all sixty will be so before January 1989—-see the Appendix, below, for particulars.

As is clear from the Appendix, we are ahead of schedule with the preparation of commentary copy (paste-ups for the KDEM or photocopy for those performing manual entry), with some 57 commentaries having been so prepared, and entered, and behind schedule in our editing (twenty-eight commentaries edited or currently being edited). This last activity has proven to be more time-consuming than we at first had estimated. We currently hope that arrangements made through the good offices of Professor Francesco Mazzoni, President of the Società Dantesca Italiana and holder of the senior chair in filologia dantesca at the University of Florence, will aid us considerably in editing computerized text. We also look forward to collaboration with Professor Antonio Zampolli, Director of the Istituto di Linguistica Computazionale (Pisa), as the project develops and finds interested users in Italy.

The extraordinarily generous response of Italian publishers holding copyright to commentaries not yet in the public domain must also be acknowledged. No major commentary which we wish to include will thus be excluded from the database. Eventual users will of 
course be reminded that material protected by the International Copyright Convention is indeed still so protected. Nonetheless, individual users will have access to this material because of the enlightened and helpful response to our requests on the part of Italian publishers.

\section{Projected Uses of the Database}

Once the project is completed, what will have been accomplished? And how will those who are interested in the database be able to consult it? Dantisti are aware that, before one ventures an opinion concerning a vexed passage, one should (or would like to) consult all previous opinions. Currently-and I speak of my own procedures in my own library's collection at Princeton-this initial effort takes roughly four days, divided as follows. Two days are necessary to collect and read through the five dozen commentaries in Firestone Library, two more to consult related bibliography (lecturae devoted to the canto in which the passage occurs, articles and books which the commentaries and the lecturae indicate as being germane). It should be added that what is described here is both the least complex and the most usual form of inquiry generated by the poem.

Our ability to complete successfully the first of these activities will now be greatly enhanced. For those who do not have access to a first-rate collection of commentaries (such as those at Cornell or Harvard) and who wish to consult widely in the commentary tradition, the Dartmouth Dante Project will become a necessity. On the other hand, those who do currently have recourse to the full run of printed commentaries will find that the computerized version has innumerable advantages. I illustrate some of these briefly.

a) A student of the poem who thinks that he has come up with an interesting interpretation of a given verse will now be able to ask for a review of the commentary tradition in whatever order may be desired (e.g., chronological, reverse-chronological, or even "myown-favored-dozen-in-the-order-I-happen-to-prefer").

b) If a scholar believes he has discovered a "source" in Virgil, Ovid, the Bible, for a given verse, he may use the search routine indicated above. He may, alternatively or additionally, wish to search the database by "key words" in order to ascertain if any of the commentators have cited his passage before him. Such searches 
require more skill on the part of the searcher, but can be extremely valuable.

c) Let us assume that one is interested not so much in Dante as the rediscovery of Plato in the Renaissance. Searches of the early commentaries for crucial concepts or phrases can be completed in seconds or minutes, depending on the richness of the materials present and the ingenuity of the searcher.

Access to the database will be achieved in a number of ways. Indeed, given the nature of the awesome speed of technological developments, it would be rash to predict in exactly what ways. What follows moves from the simplest procedures to the seemingly incredible ones.

a) retrieval possibilities in the immediate future (in all cases Dartmouth is to receive an as yet to be determined fair cost for computer time and handling of requests):

1. A print-out of a complete commentary (so long as that text is not protected by the copyright convention). Libraries or individuals wishing to fill gaps in their holdings will be able to create "instant books" should they wish to. And many of the earlier commentaries, originally printed without line references, will now have these indications-a considerable improvement.

2. A print-out of a particular comment within a commentary (e.g., Daniello on Inferno 21.112) or of all commentators on that verse or passage.

3. On-line consultation either at Dartmouth or via telephonic connection (modem). Such access allows the user full control of the search procedures and is, in most cases, to be preferred. (External users, in addition to Dartmouth's normal connection charge, will have to pay phone charges. Telenet charges between Princeton and Dartmouth currently cost about $\$ 2.50$ an hour.)

b) additional possibilities for retrieval once the project is completed:

4. A library or an individual will be able to purchase a tape of the entire database from Dartmouth for a surprisingly low fee (in the hundreds of dollars?). However, the database will be available in this form without the BRS search software. Thus a potential purchaser will need to have access to appropriate 
software at his own institution so that he will be able to interact with the database in efficient ways.

5. There is already available a laser disk (manufactured by SONY -Digital Equipment has already moved in the same direction, and others will also undoubtedly do so) which will run even now on an enhanced IBM-PC. This disk holds several times the information represented by our database. It thus seems reasonable to believe that individuals (not to mention research facilities) will be able to purchase the entire database, possibly enhanced by other texts, in a form that will run efficiently on a personal computer. It now seems almost a certainty that such will be the case well before we finish our work on the project.

\section{The User Interface}

1) The Dartmouth Dante will be menu driven.

2) "Help" features will guide users through the entire procedure of consultation.

3) Indices and tables found in some commentaries will be preserved (e.g., Scartazzini uses abbreviations to refer to other critics and commentators).

4) Since all texts are keyed by cantica, canto, and line, orderly search procedures of the most usual kind are very easily accomplished.

5) The standard search procedures of BRS will power the basic system of text retrieval. One of the distinguishing features of BRS is that it enables "full text retrieval" without prior manipulation of the database by the user.

We are aware that full text retrieval requires more complicated effort than even skilled users are likely to realize. (See the article by David C. Blair and M. E. Maron in Communications of the ACM for March of 1985.) We have reason to believe that, for various reasons, users of this database will be able to do better than those in the experiment described by Blair and Maron. At the same time, we understand the importance of making available clear and complete instructions through "help menus" concerning the various combinations of Boolean logic incorporated in BRS.

\section{Immediate plans.}

Stephen Campbell's prototype made its debut at the Kalamazoo 
Congress in May of 1987. We are now able to give interested dantisti here and abroad a more concrete sense of what the end result of our labors will enable them to accomplish. (The prototype included some two dozen commentaries to the entirety of Inferno 5.) Once we are satisfied that the prototype has dealt effectively with the problems confronting us, we should soon be able to "load" all commentaries which have been through their final editorial procedures. In October of 1988 the Project will be able to enter the "real world" and to be consulted for whatever materials are currently available. Since these materials will by then encompass at least twenty full commentaries, the gains to Dante scholarship should be worth our efforts even then, while the rest of our work continues. Each person who consults the database will be reminded that any errors should be recorded (online users will be able to list these during a session), since we will re-open the database on 20 October 1990 for the first of our regular editorial revisions of the material.

Thus, while a great deal of work still lies before us, we can begin to see that one day in a not very distant future we will have finished a task which has cost many of us considerable effort and the citizens of this republic a great deal of money.

Princeton University

\section{APPENDIX}

\section{Dartmouth Dante Project: Status of the Commentaries}

\section{(4 August 1988)}

[This chart displays the 60 commentaries chosen for inclusion. The bibliographical data are drawn from the working document, "A Checklist of Commentators on the Commedia" prepared by Robert Hollander, now available in somewhat different form in Dante Studies 101 (1983 [1988]): 181-192. The first "tier" includes Italian commentaries written before 1900; the second, Latin commentaries; the third, English; the fourth, Italian commentaries of this century. (N.B. Dates of publication are not always more than approximate.) ${ }^{*}$ An asterisk which precedes the number of an item indicates that this text is fully prepared for use. This database will be opened on 8 October 1988.] 
FIRST TIER (=earlier Italian commenaries)

*1. JACOPO ALIGHIERI (1322)

(Inferno only)

Text edited and in final form.

*2. JACOPO DELLA LANA (1324-28)

Text edited and in final form.

*3. OTTIMO (1333)

Text made available by Accademia della Crusca.

*4. ANONIMO SELMIANO (1337) (Inferno only)

Text edited and in final form.

*5. GIOVANNI BOCCACCIO (1373) (Inferno: partial)

Text edited and in final form.

6. FRANCESCO DA BUTI (1385)

Text being edited.

7. ANONIMO FIORENTINO (1400)

Text machine-readable, pre-edited but not yet edited.

8. GUINIFORTO DELLI BARGIGI (1440) (Inferno only)

Text being entered.

9. CRISTOFORO LANDINO (1481)

Text being edited.

10. ALESSANDRO VELLUTELLO (1544)

Text being edited.

*11. BERNARDINO DANIELLO (1568)

Text edited and in final form-printed edition expected shortly.

12. LODOVICO CASTELVETRO (1570) (Inferno: partial)

Text being edited (expected 9/88).

13. POMPEO VENTURI (1732)

Text machine-readable, not yet pre-edited.

14. BALDASSARE LOMBARDI (1791)

Text being edited (expected 9/88).

15. LUIGI PORTIRELLI (1804)

Text machine-readable, pre-edited but not yet edited.

*16. PAOLO COSTA (1819)

Text edited and in final form.

17. ROSSETTI (1826)

(Inferno \& Purgatorio)

Text ready for data entry.

18. NICCOLÒ TOMMASEO (1837)

Text being edited (ready fall 1988). 
19. RAFFAELLO ANDREOLI (1856)

Text machine-readable, not yet pre-edited.

20. LUIGI BENNASSUTI (1864)

No action taken as yet (last comm. in this list at this stage).

21. GREGORIO DI SIENA (1867)

(Inferno only)

Text being entered.

*22. BRUNONE BIANCHI (1868)

Text edited and in final form.

23. G. A. SCARTAZZINI (1900 [1874])

Text machine-readable, not yet pre-edited.

24. GIUSEPPE CAMPI (1888)

Text ready for data entry.

25. GIOACHINO BERTHIER (1892)

(Inferno only)

Text being entered.

26. GIACOMO POLETTO (1894)

Text machine-readable, not yet pre-edited.

SECOND TIER (Latin Commentators)

27. GRAZIOLO DE' BAMBAGLIOLI (1324) (Inferno only)

Text being edited (ready early 1989?).

28. ANONIMO LOMBARDO (1324?) (Purgatorio only)

Text machine-readable, not yet pre-edited.

*29. GUIDO DA PISA (1327)

(Inferno only)

Text edited and in final form (as of 9/1/88).

*30. PIETRO DI DANTE (1340)

Text edited and in final form.

31. CODICE CASSINESE (1350??)

Text machine-readable, pre-edited, but not yet edited.

32. BENVENUTO DA IMOLA (1373)

Text machine-readable and being edited (through Inferno).

*33. JOHANNIS DE SERRAVALLE (1416)

Text edited and in final form (by 9/15/88).

\section{THIRD TIER (English Commentators)}

\section{HENRY WADSWORTH LONGFELLOW (1867)}

Text machine-readable, not yet pre-edited.

35. H. OELSNER (1899)

Text being entered. 
36. H. F. TOZER (190I)

Text being entered.

*37. JOHN RUSKIN (1903)

Text edited and in final form.

38. J. S. CARROLL (1904)

Text machine-readable, not yet pre-edited.

39. C. H. GRANDGENT (1909)

Text machine-readable, pre-edited, but not yet edited.

40. CHARLES S. SINGLETON (1970)

Text machine-readable, pre-edited, but not yet edited.

\section{FOURTH TIER (Modern Italian Commentators)}

41. FRANCESCO TORRACA (1905)

Text machine-readable, not yet pre-edited.

42. CARLO STEINER (1921)

Text machine-readable, not yet pre-edited.

43. ENRICO MESTICA (1921)

Text machine-readable, being pre-edited, but not yet edited.

*44. CASINI/BARBI (1921)

Text edited and in final form.

45. ISIDORO DEL LUNGO (1926)

Data entry in progress.

46. SCARTAZZINI/VANDELLI (1929)

Text machine-readable, not yet pre-edited.

47. CARLO GRABHER (1934)

Text machine-readable, not yet pre-edited.

48. ERNESTO TRUCCHI (1936)

Text machine-readable, not yet pre-edited.

49. DINO PROVENZAL (1938)

Text machine-readable and being edited.

50. LUIGI PIETROBONO (1946)

Text machine-readable, not yet pre-edited.

*51. ATTILIO MOMIGLIANO (1946)

Text edited and in final form.

*52. MANFREDI PORENA (1946)

Text edited and in final form.

*53. NATALINO SAPEGNO (1955)

Text edited and in final form. 
54. DANIELE MATTALIA (1960)

Data entry in progress.

55. SIRO A. CHIMENZ (1962)

Text machine-readable, not yet pre-edited.

56. GIOVANNI FALLANI (1965)

Text machine-readable, pre-edited, soon to be edited.

*57. GIORGIO PADOAN (1967)

Text edited and in final form.

*58. GIUSEPPE GIACALONE (1968)

Text edited and in final form (Inf. \& Purg.; Par. in 1989).

*59. BOSCO/REGGIO (1979)

Text edited and in final form.

60. PASQUINI/QUAGLIO (1982)

Data entry in progress.

Summary of Progress to Date (1984-88)

Commentaries fully edited: $\quad 19$

being edited: 9

ready to be edited: $\quad 7$

entered, awaiting pre-edit: $\quad 14$

being entered: $\quad 8$

ready to be entered: 2

being prepared for entry: 1 